\title{
Clinical and Pathological Characteristics of The Patients with Kaposi Sarcoma: A Single Center Study
}

\author{
Kaposi Sarkomunun Klinik ve Patolojik Özellikleri: Tek \\ Merkez Çalışması
}

Zeynep Bayramoglu ${ }^{1}$

Yasar Unlu ${ }^{1}$

${ }^{1}$ Department of Pathology, Konya Training and Research Hospital, Konya, Turkey

Geliş Tarihi/Received: 28 January 2019 Kabul Tarihi/Accepted: 15 April 2019

Address correspondence to: Zeynep Sonuç: Bizim çalışmamızda Konya'da görülen KS'larının geç yaş başlangıçı olduğu ve erkeklerde Bayramoglu, Department of Pathology, Konya daha sık görüldüğü izlenmiştir. Retrospektif olarak değerlendirdiğimiz olguların demografik bilgileri ve Training and Research Hospital, Konya, histopatolojik tipler açısından literatürde sunulan çalışmalarla benzerlikler gösterdiği görülmektedir.

Turkey

e-mail: drzeynepbayramoglu@hotmail.com

\section{ORCID}

Zeynep Bayramoglu

https://orcid.org/0000-0001-7075-8819

Yasar Unlu

https://orcid.org/0000-0002-3951-8881
Anahtar Kelimeler: Kaposi sarkomu, immünohistokimya, histopatoloji

\section{Abstract}

Aim: Kaposi sarcoma (KS) is a vascular proliferative disease associated with human herpesvirus-8 (HHV8). The studies about the epidemiology of KS in Turkey are limited. We aimed to evaluate the clinical, pathological, and immunohistochemical features a total of $78 \mathrm{KS}$ patients, presenting them along with the available information in the literature.

Patients and Methods: We retrospectively evaluated the clinical and histopathological characteristics of a total of 78 patients with KS.

Results: The age of the patients ranged from 46 to 93 years and the mean age was 74.06 years. Of the patients, 59 were males and 19 were females. The lesions were most commonly found on the lower extremities. In the study patients, KS was found both at earlier stages with patches or plaques in 54 of the patients and at the nodular stage in 24 patients. A punch biopsy or an excisional biopsy was performed in 23 and 55 patients, respectively. In the excisional biopsies, the smallest tumor diameter was $0.35 \mathrm{~cm}$ and the largest one was $2.8 \mathrm{~cm}$ with a mean diameter of $0.98 \mathrm{~cm}$

Conclusion: This retrospective study demonstrated that; in Konya, KS developed in older people and it was most commonly seen in males. It was observed that the demographic features and histopathological types of KS in the study patients were similar to the reports in the literature.

Key words: Kaposi sarcoma, immunohistochemistry, histopathology

\section{INTRODUCTION}

Kaposi sarcoma (KS) is a locally aggressive vascular neoplasm associated with human herpesvirus-8 (HHV-8) and is composed of dermal spindle cells. KS was first described as "the idiopathic multiple pigmented sarcoma of the skin" by Moritz Kaposi in 1872, based on the multifocal and symmetrical skin lesions on the lower extremities in 5 patients (1). KS can be seen at any age and in both genders; however, it is more common in adults and in males. The incidence of KS in the world is 0.6 in 100.000 with a male/female ratio of 1.9:1. The etiological agent causing $\mathrm{KS}$ is HHV-8 from the Gammaherpesvirinae subfamily (2). KS is conventionally classified into 3 distinct subtypes; comprising patch-stage, plaquestage, and well-developed (nodular) KS. Furthermore, 16 histopathological variants of KS have been defined including anaplastic (pleomorphic), lymphangiomalike (lymphangiomatous), lymphangiectatic, telangiectatic, bullous, cavernous hemangioma-like, 


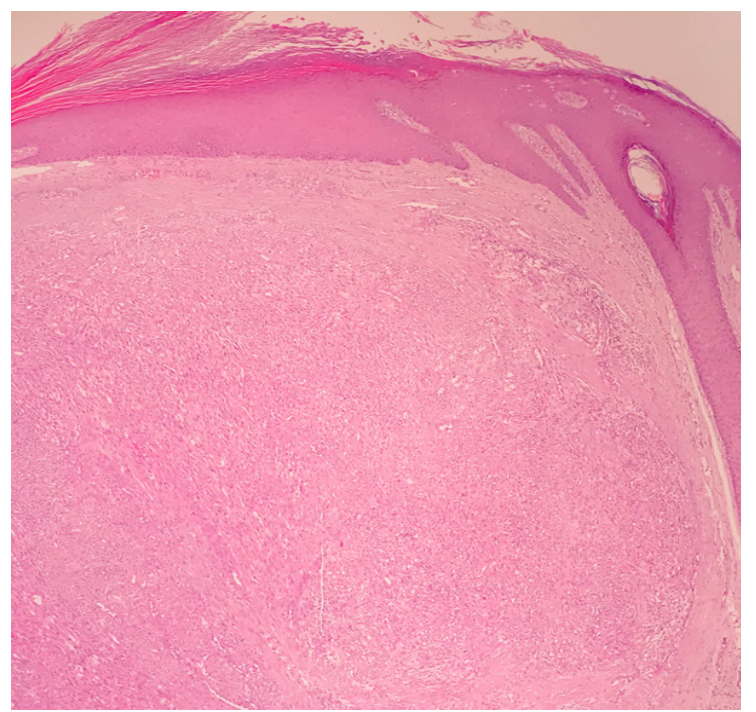

Figure 1. Proliferating spindle cells under the epidermis in histopathological examination (H\&E 4X).

hyperkeratotic (verrucous), keloidal, micronodular, pyogenic granuloma-like, ecchymotic, intravascular, glomeruloid, pigmented, and regressing/regressed type KS, and KS with myoid nodules. However, histopathological variants are rare (2). KS lesions are most commonly seen in the lower extremities, followed by the face and the genital region. Mucosal involvement is also common, particularly in the oral mucosa (2). From the clinicopathological aspect, $\mathrm{KS}$ is classified into four subtypes, which are the iatrogenic,

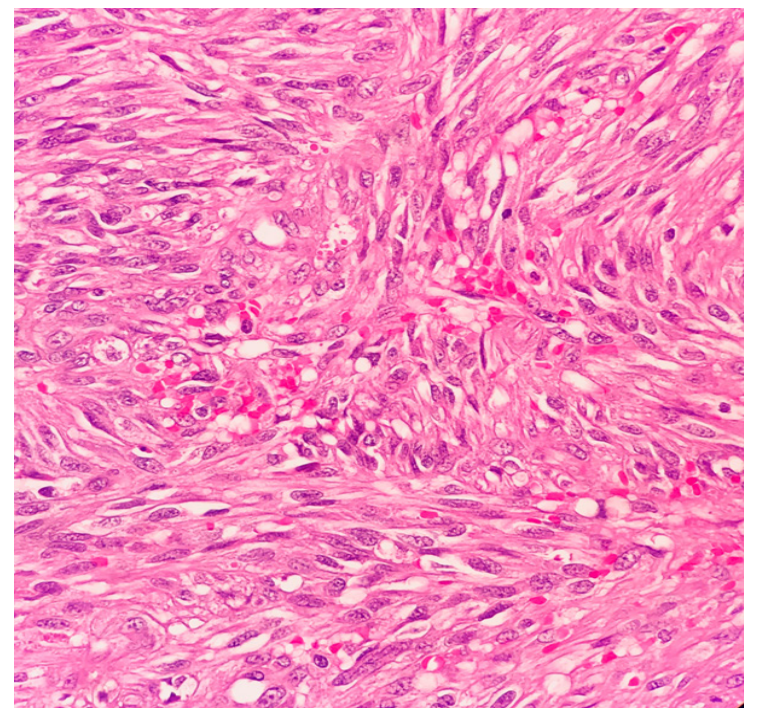

Figure 2. Erythrocytes are present among these spindle cells (H\&E 40X).

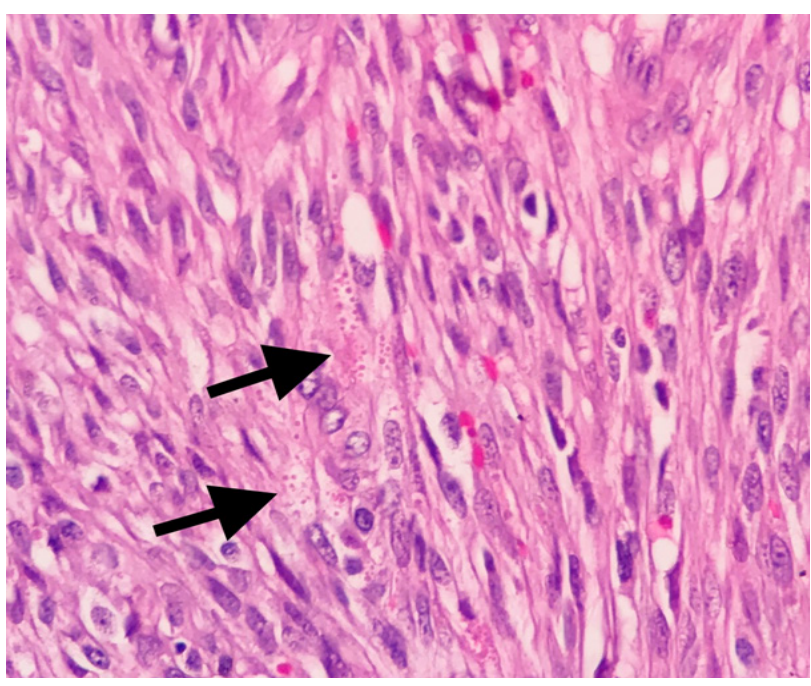

Figure 3. Extracellular and intracellular hyaline globules (H\&E 40X).

AIDS-associated, African, and classic KS.

\section{PATIENTS AND METHODS}

This study retrospectively evaluated the clinical characteristics and the macroscopic, histopathological, and immunohistochemical features of the lesions in a total of 78 patients, who were diagnosed with KS histopathologically.

\section{RESULTS}

The age of the study patients ranged from 46 to 93 years and the mean age was 74.06 years. Of our patients, 59 were males and 19 were females. Male to female ratio in the study was $3.1 / 1$. The lesions were

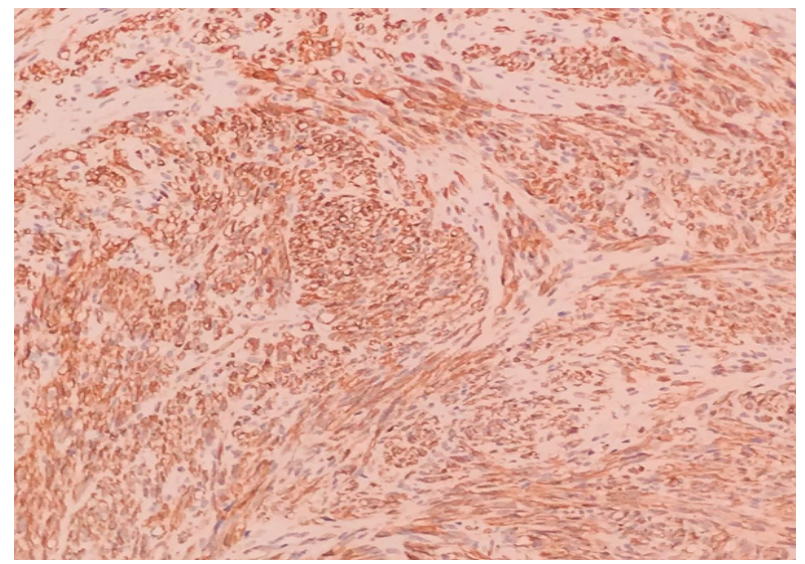

Figure 4. Positive reaction with CD34 in immunohistochemical examination (10X) 


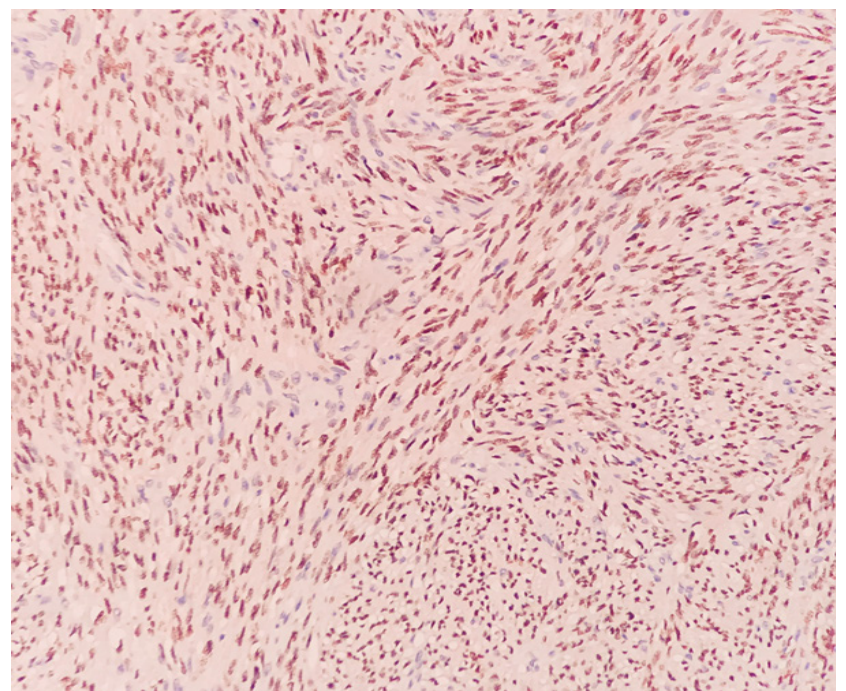

Figure 5. Positive reaction with HHV-8 in immunohistochemical examination (10X)

on the lower extremities in 59 patients, on the upper extremities in 14 patients, on the face in 2 patients, on the penis in 2 patients, and on the breast in 1 patient. Of the study patients; 54 were diagnosed with the patch or plaque stages of $\mathrm{KS}$, which were classified as the early stages of KS, and 24 patients were diagnosed with the nodular stage. A punch biopsy was performed in 23 patients and an excisional biopsy was performed in 55 patients. In the excisional biopsies, the smallest tumor diameter was $0.35 \mathrm{~cm}$ and the largest one was $2.8 \mathrm{~cm}$. The mean tumor diameter was $0.98 \mathrm{~cm}$. Basal cell carcinoma was found only in 1 patient comorbid with KS. None of the study patients was infected with human immunodeficiency virus (HIV).

The histopathological changes were less definite in the early stage lesions, in which slightly enlarged endothelial cells lined up the irregular vascular clefts in the superficial and deep dermis. Mononuclear inflammatory cell infiltration was observed in the perivascular areas between the irregular vascular clefts. In the nodular lesions, the proliferation of spindle cells was observed surrounding the proliferated vascular clefts (Figure 1-2). Erythrocytes were present among these spindle cells. Intracellular or extracellular hyaline globules, which were positively stained for PAS, were also observed in the histopathological examination as they can be seen at any stage of KS (Figure 3 ). In our cases, there was a positive reaction with CD34 and HHV8 in immunohistochemical examination (Figure 4-5).

\section{DISCUSSION}

$\mathrm{KS}$ is a rare angioproliferative tumor. KS lesions are typically found on the skin and on the mucosal surfaces. The lesions of KS are characterized by purplish, red-blue or brown-black macules, papules, and nodules, which will likely to bleed and ulcerate. A definite diagnosis is possible with histopathological and immunohistochemical examination (3). Although the role of HHV-8 in the pathogenesis of Kaposi sarcoma has been established clearly; genetic, immunological or environmental factors are also involved (4). Human herpesvirus 8 (HHV-8) or KS-associated herpesvirus plays a major role in the development of KS. The virus interacts and encodes several proteins in the body, which are the latency-associated nuclear antigen, viral G protein-coupled receptor, viral FLICE inhibitory protein, and viral IL-6. Finally, the tumor develops on the skin primarily but it can develop in various organs as well (5-6).

$\mathrm{KS}$ is more common in the Mediterranean countries compared to other countries in the world; however, there have been only four studies reported from our country by Su et al., Gün et al., Demirel et al., and Polat et al., (7-10) investigating the demographic and clinical features of KS. The geographical distribution of HHV-8 is significantly variable in the world, showing parallel variations in the incidence of the disease. It is suggested that the variations in the incidence of the disease among the countries in the world result from differences in the socioeconomic status, sexual life, and the genotypes of the host and the virus (11). Our study results were consistent with the reports in the literature. Most of the patients were males and the mean age of the patients was 74.06 years. A multicentre study from Europe reported that the general incidence rate of KS was 3.0 in a million (12). A study from Israel evaluated 2107 patients with KS in a period of 38 years, reporting that the age of diagnosis increased in both males and females during that period. This result was suggested to be related to the combination of two factors, which were the slowly progressing nature of the disease and the increased human lifespan (13). In our patients; consistently with the literature, the lesions were most commonly located on the lower extremities, followed by the lesions found on the upper extremities.

Cellular origins and neoplastic characteristics of KS are still debatable. Spindle-shaped cells are the most common cells found in nodular lesions. These cells are also known as Kaposi cells and they react positively with several markers including 
CD31, CD34, FVIII, VEGFR3, LYVE1, D2-40, and podoplanin $(14,15)$. Furthermore, spindle cells may express Factor XIII, CD68, and SMA (16). All these distinct immunohistochemical staining characteristics suggest the involvement of more than one cell type. Vascular changes have also been reported in the complex pathogenesis of KS with the findings reported by in vitro studies demonstrating that the endothelial cells of the blood vessels were infected with KSHV. It has been reported that this infection at the cellular level activates endothelial markers. In addition, lymphatic cells have also been reported to be infected. It has been suggested that all these changes start a sequence of events towards the reprogramming of the blood vessels $(17,18)$.

Immunohistochemical staining in vascular tumors mainly aims to demonstrate epithelial cell differentiation. Secondly, it allows for making a routine histopathological diagnosis. For these purposes, the specimens collected from our patients were all applied CD34 and FVIII. FVIII is a protein synthesized by the endothelial cells and is a favorable marker for demonstrating endothelial cell differentiation. CD34 is not specific to the endothelial cells but strongly expressed in the vascular endothelium, especially in pathological states (19). Immunohistochemical reactions with CD34 and FVIII were observed in all of the specimens collected from our study patients (19). FVIII expression was observed in the cleftlike vascular structures in the tissue specimens. The spindle cells were positive for CD34 by immunohistochemical staining. The differential diagnosis included progressive lymphangioma, acroangiodermatitis, pyogenic granuloma, hobnail hemangioma, spindle cell hemangioma, Kaposiform hemangioendothelioma, angiosarcoma, and cellular fibrous histiocytoma $(2,20)$. The differential diagnosis of Kaposi sarcoma is summarized in Table 1.

The comorbidities of KS were previously reported in the studies from Turkey. Su et al. $(7,8,10)$ reported that colon and stomach adenocarcinomas were comorbid with KS. In their study, Demirel et al. reported that

Table 1. The differential diagnosis of Kaposi sarcoma.

Progressive Iymphangioma

Acroangiodermatitis

Pyogenic granuloma

Hobnail hemangioma

Spindle cell hemangioma

Kaposiform hemangioendothelioma

Angiosarcoma

Cellular fibrous histiocytoma
-Thin-walled vascular clefts parallel to the surface are observed dissecting the collagen.

-There are no spindle cells or extravasated erythrocytes

-The proliferation of thick-walled and dilated vessels is observed in the papillary dermis.

-Extravasated erythrocytes, siderophages, and fibrosis are observed at the bottom of the lesions.

-Dermal spindle cells are fibroblasts.

-There are no spindle cells.

-Intraluminal papillary protrusions and fibrinous thrombi are present.

-The periphery of the lesions may display some characteristic findings similar to those seen in KS.

-A biphasic pattern with the development of both cavernous and cellular structures is observed.

-There are dilated blood vessels.

-Clearly visible cytoplasmic vacuoles are present in the epithelioid cells.

-Most commonly seen in infants and children.

-The growth pattern is lobular.

-The vascular clefts are larger and the epithelioid cells bear

the characteristics of epithelioid structures more.

-The differential diagnosis of low-grade angiosarcoma and KS is particularly difficult.

-There is cellular atypia.

-There is epidermal hyperplasia.

-Spindle cells react negatively to vascular markers. 
they found colon and prostatic carcinomas comorbid with KS. Finally, the study conducted by Polat et al. reported that lymphoma, thyroid carcinoma, and bladder carcinoma were comorbid with KS. In our study, only one patient had a comorbid basal cell carcinoma with KS. Several studies have been conducted recently on KS and its tumorigenesis. A study reported the activation of two oncoproteins, which were YAP/TAZ, in KS. These were reported to be homologous proteins and their activities were inhibited by the Hippo tumor suppressor pathway. However, they were found to be activated in KSHV infected cells in vitro, in KS-like mouse tumors, and in human KS specimens clinically (21).

\section{CONCLUSION}

In our study, we observed that Kaposi sarcoma in Konya had a late disease onset and was more common in males. The differential diagnosis process revealed that the lesions of KS were most commonly found in the earlier disease stages. The retrospective evaluation of the cases demonstrated that the demographical and clinical findings of the study patients, as well as the subtypes of the lesions, were similar to the other study reports in the literature.

Conflict of interest: Authors declare that there is no conflict of interest between the authors of the article.

Financial conflict of interest: Authors declare that they did not receive any financial support in this study.

Address correspondence to: Zeynep Bayramoglu, Department of Pathology, Konya Training and Research Hospital, Meram, Konya, Turkey

Telephone: +905309387775

e-mail: drzeynepbayramoglu@hotmail.com

\section{REFERENCES}

1. Kaposi M. Idiopathisches multiples pigmentsarkom der haut. Arch Dermatol Syph 1872;4,265-73.

2. Elder DE, Massi D, Scolyer RA, et al. WHO classification of skin tumours. International Agency for Research on Cancer, 2018.

3. Mentzel T, Knuutila S, Lamovec J. Kaposi sarcoma. In: Fletcher CDM, Bridge JA, Hogendoorn PCW, Mertens F, editors. World Health Organisation classification of tumours of soft tissue and bone. 4th ed. Lyon: IARC Press; 2013. pp. 151-3.

4. Liu G, Yu FX, Kim YC, et al. Kaposi sarcoma-associated herpesvirus promotes tumorigenesis by modulating the Hippo pathway. Oncogene 2015;34(27),3536.

5. Hbid O, Belloul L, Fajali N, et al. Kaposi's sarcoma in Morocco: A pathological study with immunostaining for human herpesvirus-8 LNA-1. Pathology 2005;37(4),288-95.
6. Mesri EA, Cesarman E, Boshoff C. Kaposi's sarcoma herpesvirus/Human herpesvirus-8 (KSHV/HHV8), and the oncogenesis of Kaposi's sarcoma. Nature reviews. Cancer 2010;10(10),707.

7. Demirel BG, Koca R, Tekin NS, et al. Klasik kaposi sarkomu: Yetmis dört hastanin klinik, demografik özellikleri ve tedavi sonuçlarinin degerlendirilmesi/Classic Kaposi's sarcoma: The clinical, demographic and teratment characteristics of seventy-four patients. Turkderm 2016;50(4),136.

8. Su Ö, Onsun N, Arda $\mathrm{H}$, et al. Klasik kaposi sarkomlu olgularda klinik özellikler, insan herpesvirüs-8'in varlığı ve tedavi sonuçları. TÜRKDERM-Deri Hastalıkları ve Frengi Arşivi 208;42(4),122-6.

9. Gün BD, Bahadır B, Ekem TE, et al. Klasik kaposi sarkomu: Klinik ve immünohistokimyasal özellikler. Turkiye Klinikleri Journal of Dermatology 2007;17(1), 21-5.

10. Polat AK, Karaali MG, Aksu AEK, et al. Evaluation of clinical course, histopathological and treatment characteristics of patients with Kaposi's sarcoma. Evaluation 2018;52,131-6.

11. Tiussi RM, Caus ALDO, Diniz LM, et al. Kaposi's sarcoma: Clinical and pathological aspects in patients seen at the Hospital Universitário Cassiano Antônio Moraes-VitóriaEspírito Santo-Brazil. Anais Brasileiros de Dermatologia 2012;87(2), 220-7.

12. Stiller CA, Trama A, Brewster DH, et al. Descriptive epidemiology of kaposi sarcoma in Europe. Report from the Rarecare project. Cancer epidemiology 2014;38(6),670-8.

13. Guttman-Yassky E, Bar-Chana $M$, Yukelson $A$, et al. Epidemiology of classic kaposi's sarcoma in the israeli jewish population between 1960 and 1998. British journal of cancer 2003;89(9),1657.

14. Jussila L, Valtola R, Partanen TA, et al. Lymphatic endothelium and kaposi's sarcoma spindle cells detected by antibodies against the vascular endothelial growth factor receptor-3. Cancer Research 1998;58(8),1599-604.

15. Dupin N, Fisher C, Kellam P, et al. Distribution of human herpesvirus-8 latently infected cells in Kaposi's sarcoma, multicentric castleman's disease, and primary effusion lymphoma. Proceedings of the National Academy of Sciences 1999;96(8),4546-51.

16. Roth WK, Brandstetter $\mathrm{H}$, Sturzl M. Cellular and molecular features of HIV-associated kaposi's sarcoma. Aids 1992;6(9), 895-914.

17. Hong YK, Foreman K, Shin JW, et al. Lymphatic reprogramming of blood vascular endothelium by kaposi sarcoma-associated herpesvirus. Nature genetics 2004;36(7),683.

18. Wang HW, Trotter MW, Lagos D, et al. Kaposi sarcoma herpesvirus-induced cellular reprogramming contributes to the iymphatic endothelial gene expression in kaposi sarcoma. Nature genetics 2004;36(7),687.

19. Pusztaszeri MP, Seelentag W, Bosman FT. Immunohistochemical expression of endothelial markers CD31, CD34, von Willebrand factor, and Fli-1 in normal human tissues. Journal of Histochemistry \& Cytochemistry 2006;54(4),385-95.

20. Weiss SW, Goldblum JR. Enzinger and Weiss's Soft Tissue Tumors. 4th ed. St Louis: Mosby; 2001. p.917-54.

21. Liu G, Yu FX, Kim YC, et al. Kaposi sarcoma-associated herpesvirus promotes tumorigenesis by modulating the Hippo pathway. Oncogene 2015;34(27),3536. 